\title{
EFEK MEDAN ELEKTROMAGNET PADA MESIN BENSIN TERHADAP EMISI GAS BUANG DAN ENERGI PEMBAKARAN
}

\author{
Tatun H Nufus ${ }^{1)}$, Andi Ulfiana ${ }^{1)}$, Isnanda Nuriskasari ${ }^{1)}$, Emir Ridwan $^{1)}$, Sri Lestari ${ }^{2)}$ \\ ${ }^{1}$ Teknik Mesin, Politeknik Negeri Jakarta, Jalan. Prof. Dr. G.A Siwabessy, \\ Jawa Barat 16242, Indonesia. \\ ${ }^{2}$ Teknik Elektro, Politeknik Negeri Jakarta, Jalan. Prof. Dr. G.A Siwabessy, \\ Jawa Barat 16242, Indonesia. \\ email: ${ }^{1}$ tatun.hayatun@mesin.pnj.ac.id, ${ }^{1}$ isnanda.nuriskasari@mesin.pnj.ac.id, \\ ${ }^{1}$ andi.ulfiana@mesin.pnj.ac.id, ${ }^{2}$ sri.lestrai@elektro.pnj.ac.id
}

\begin{abstract}
Abstrak
Tujuan penelitian ini menganalisis efek medan elektromagnet terhadap kualitas pembakaran terutama pada mesin besin. Salah satu indikator kualitas pembakaran yang baik adalah emisi gas buang ramah lingkungan dan energi pembakaran relatif besar. Penelitian ini menggunakan metoda eksperimen, dengan variabel bebas kuat medan magnet dan bahan bakar. Kuat medan yang digunakan pada penelitian terdiri dari 4 variasi yaitu 647 Gauss, 847 Gauss, 1068 Gauss dan 1419 Gauss sedang bahan bakar yang digunakan adalah E0 (premium 100\% bioetanol 0\%), E10 (premium 90\% bioetanol 10\%), E20 (premium 80\% bioetanol 20\%), dan E30 (premium 70\% bioetanol 30\%). Parameter kuat medan elektromagnet dan berbagai jenis komposisi bahan bakar digunakan untuk menguji emisi gas buang dan energi pembakaran (sebagai variabel terikat) pada motor bensin MIO $125 \mathrm{cc}$ tahun 2018. Hasilnya kadar emisi gas buang $\mathrm{CO}_{2}$ meningkat hingga 35\% dan kadar $\mathrm{CO}$ menurun hingga $71 \%$, energi pembakaran meningkat berkisar $13-21 \%$. Makin besar medan elektromagnet yang diberikan, maka emisi gas buang makin ramah lingkugan dan energi pembakaran makin besar.
\end{abstract}

Kata kunci: energi, pembakaran, elekromagnet, gas buang.

\begin{abstract}
The purpose of this study was to analyze the effects of electromagnetic fields on combustion quality, especially on gasoline engines. One of the indicators of good combustion quality was environmentally friendly exhaust emissions and relatively large combustion energy. This research uses an experimental method, with the independent variables magnetic field strength and fuel. The field strength used in this study consisted of 4 variations, namely 647 Gauss, 847 Gauss, 1068 Gauss and 1419 gauss, while the fuel used was EO (premium 100\% bioethanol 0\%), E10 (premium 90\% bioethanol 10\%), E20 (premium 80\% bioethanol 20\%), and E30. (premium 70\% bioethanol 30\%). The parameters of the electromagnetic field strength and various types of fuel composition were used to test exhaust gas emissions and combustion energy (as the dependent variable) on the $125 \mathrm{cc} M \mathrm{MIO}$ gasoline motorbike in 2018.The result was that the levels of CO2 exhaust emissions increased by 35\% and CO levels decreased by $71 \%$, combustion energy increases in the range of $13-21 \%$. The greater the electromagnetic field provided, the more environmentally friendly the exhaust emissions are and the greater the combustion energy.
\end{abstract}

Keyword: energy, combustion, electromagnet, exhaust gas emission. 


\section{PENDAhuluan}

Salah satu faktor penyebab kinerja mesin bensin menurun adalah proses pembakaran yang tidak sempurna dan berefek pada emisi gas buang yang tidak ramah lingkungan serta energi pembakaran yang menurun. Berbagai cara dilakukan untuk mengatasi permasalahan di atas, di antaranya menggunakan bahan bakar nabati yang ramah lingkungan seperti bioetanol. Pencampuran bahan bakar antara bensin dan bioetanol dengan komposisi tertentu mampu menciptakan pembakaran yang lebih sempurna, karena bioetanol bersifat oxygenating agent atau mengandung oksigen yang lebih banyak dari bensin. Temperatur pembakaran bioethanol lebih tinggi dari bensin sehingga pembakaran yang merata sulit tercapai pada tekanan kompresi di ruang bakar (Syarifuddin, Tony, \& Utomo, 2016). Untuk mengatasi kekurangan penggunaan bioetanol dicoba dengan menggunakan medan elektromagnet. Berdasarkan beberapa penelitian medan elektromagnet mampu membuat molekul bahan bakar menjadi lebih halus sehingga pencampuran udara dan bahan bakar menjadi lebih homogen (Siregar \& Nainggolan, 2012); (Nufus, Praeko, Setiawan, \& Hermawan, 2017).

Alat peningkat kualitas pembakaran berbasis medan elektromagnetik ini dipasang pada pipa bahan bakar sebelum ruang bakar. Keberhasilan alat ini pada sepeda motor diindikasikan dengan menurunnya kadar emisi gas buang CO, NO dan HC (Kolhe, Shelke \& Khandare, 2014), (L. S. Khuong et al , 2017). Medan elektromagnet mampu membuat molekul hidrokarbon yang awalnya bergumpal menjadi tidak bergumpal atau terpecah menjadi molekul yang lebih kecil. Hal ini diperlukan agar bahan bakar dapat dengan mudah mengikat oksigen selama proses pembakaran, sehingga campuran bahan bakar dan oksigen dapat terbakar dengan sempurna (Chaware, 2015). Kualitas pembakaran yang baik diindikasikan dengan pembakaran sempurna yang tidak menghasilkan gas berbahaya dan akan menghasilkan energi pembakaran yang besar (Subbarayan MR, Kumaar JSS, Padmanaban MRA. 2016). Skema reaksi pembakaran pada mesin disajikan pada Gambar 1 .

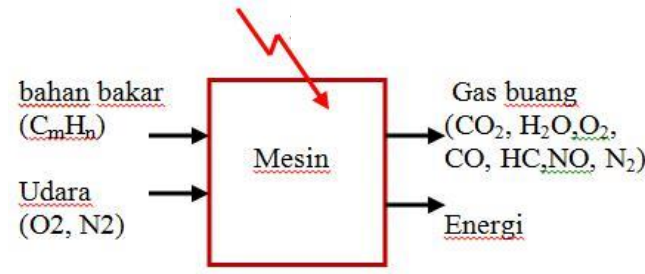

Gambar 1. Reaksi bahan bakar dan udara menjadi energi dan emisi gas buang.

Pembahasan terkait dengan energi pembakaran yang dihasilkan dari penggunaan medan elektromagnet pada mesin bensin dengan bahan bakar campuran antara premium dan bioetanol belum dijelaskan pada penelitian di atas. Oleh karena itu, tujuan penelitian adalah membuktikan bahwa penggunaan medan elektromagnet dapat menghasilkan emisi gas buang yang ramah lingkungan dan dapat meningkatkan energi pembakaran. Untuk menghitung energi pembakaran digunakan hasil uji emisi gas buang diantaranya $\mathrm{CO}_{2}$, $\mathrm{H}_{2} \mathrm{O}$, CO dan $\mathrm{N}_{2}$, sebelum dan sesudah menggunakan medan elektromagnet.

\section{METODE}

Metode penelitian dilakukan secara eksperimental dan didukung teori yang relevan misalnya rumus stoikiometri dan termodinamika. Data diperoleh dengan pengamatan langsung dan pengukuran di lapangan dengan alat ukur yang tersedia. Mesin yang digunakan untuk penelitian adalah sepeda motor bensin 4 langkah sistem injeksi kapasitas silinder $125 \mathrm{cc}$ dengan spesifikasi mesin terlihat pada Tabel 1 .

Tabel 1. Spesifikasi mesin bensin (Yamaha, 2020)

\begin{tabular}{lc}
\hline Tipe mesin & $\begin{array}{c}\text { 4 Langkah SOHC, } \\
\text { berpendingin udara }\end{array}$ \\
\hline Diameter x langkah & $52.4 \times 57.9 \mathrm{~mm}$ \\
Volume silinder & $125 \mathrm{cc}$ \\
Perbandingan kompresi & $9.5: 1$ \\
Power Maksimum & $7 \mathrm{~kW} / 8000 \mathrm{rpm}$ \\
Torsi Maksimum & $9.6 \mathrm{Nm} / 5500 \mathrm{rpm}$ \\
Oli Mesin & 0.84 liter \\
Sistem pengapian & TCI/ Fuel Injection \\
Sistem Kopling & Kering, Centrifugal \\
& Automatic \\
\hline
\end{tabular}

Kuat medan magnet yang digunakan 647 Gauss, 847 Gauss, 1068 Gauss dan 1419 Gauss. Medan magnet diukur menggunakan alat ukur teslameter. Sedangkan bahan bakar yang digunakan adalah E0, E10, E20 dan E30. Spesifikasi bahan bakar yang digunakan disajikan pada tabel 2 .

Tabel 2. Spesifikasi bahan bakar (Agathou \& Kyritsis, 2012)

\begin{tabular}{lll}
\hline Property & Bensin & Bioetanol \\
\hline Formula (liquid) & $\mathrm{C}_{8} \mathrm{H}_{18}$ & $\mathrm{C}_{2} \mathrm{H}_{5} \mathrm{OH}$ \\
$\begin{array}{l}\text { Molecular weight (g/mol) } \\
\text { Density (kg/m3) }\end{array}$ & 11.15 & 46.07 \\
$\begin{array}{l}\text { Heat of vaporization (kJ/kg) } \\
\begin{array}{l}\text { Stoichiometric air-fuel ratio } \\
\text { by mass }\end{array}\end{array}$ & 305 & 785 \\
$\begin{array}{l}\text { Research octane number } \\
\text { Motor octane number }\end{array}$ & 92 & 840 \\
$\begin{array}{l}\text { Specific heat (kJ/kgK) } \\
\text { liquid }\end{array}$ & 85 & 89.7 \\
$\begin{array}{l}\text { Specific heat (kJ/kgK) } \\
\text { vapour }\end{array}$ & 2.4 & 1.7 \\
$\begin{array}{l}\text { Lower heating value } \\
\text { Enthalphy of formation } \\
\text { (MJ/kmol) liquid }\end{array}$ & 2.5 & 1.93 \\
\hline
\end{tabular}

Seluruh peralatan penelitian dikalibrasi, selanjutnya dilakukan pengecekan komponen mesin bensin seperti minyak pelumas, filter oli pelumas dan 
filter bahan. Semua instrumen dirangkai seperti yang ditunjukkan pada Gambar 2.

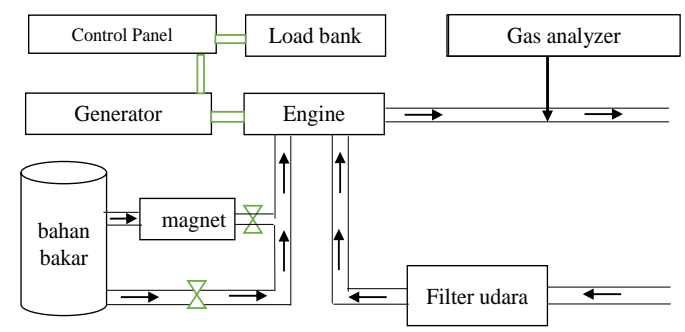

Gambar 2. Instalasi alat pengujian

Prosedur Pengukuran emisi gas buang dan konsumsi bahan bakar

Gambar 2 menyajikan skema pengujian emisi bahan bakar pada mesin bensin, prosedur pengujian sebagai berikut:

1. Dipasang komponen pompa bensin eksternal pada motor

2. Isi bahan bakar pada gelas ukur atau penampung bahan bakar eksternal

3. Buka keran bensin, nyalakan pompa bensin eksternal hingga seluruh saluran selang terisi bensin

4. Nyalakan mesin selama 1 menit untuk memastikan tidak ada udara terperangkap di saluran bensin

5. Tutup keran saluran bensin, lalu matikan motor

6. Untuk uji Magnet: nyalakan magnet yang telah terisi BBM, tunggu selama 20 menit

7. Setelah 17 menit lalu hidupkan mesin selama 3 menit dengan membuka keran jalur BBM yang tidak melalui magnet. Tujuannya adalah untuk mencapai suhu kerja optimum mesin.

8. Setelah 20 menit maka dilakukan pengukuran konsumsi bahan bakar dengan cara membuka keran BBM yang melalui magnet, dan tutup keran yang tidak melalui magnet.

9. Dalam kondisi mesin hidup dengan putaran konstan 2000 rpm, lakukan pengukuran volume BBM awal di gelas ukur tersebut. Kemudian hidupkan timer untuk 10 menit.

10. Pada exhaust dipasang gas analyzer untuk mengamati efek gas buangnya.

11. Lakukan hal yang sama untuk sampel berikutnya.

Bahan bakar bensin, bioetanol dan udara masuk kedalam mesin, setelah proses pengisapan, kompresi, pembakaran, kerja dan buang. Energi panas akan berubah menjadi energi potensial untuk menggerakkan piston sehingga terjadi kerja. Selain itu mesin mengeluarkan gas buang yang mengandung gas $\mathrm{CO}_{2}$, $\mathrm{H}_{2} \mathrm{O}, \mathrm{O}_{2}, \mathrm{CO}, \mathrm{HC}$, NO, dan $\mathrm{N}_{2}$ (Mariaca, A. G. and Castaño, R. M. Anhydrous, 2018), (R. A. S. N and B. Sudarmanta, 2018) . Pada pembahasan ini gas yang diperhitungkan hanya $\mathrm{CO}_{2}, \mathrm{H}_{2} \mathrm{O}, \mathrm{CO}$, dan $\mathrm{N}_{2}$. selanjutnya dari nilai $\mathrm{CO}_{2}$ dan $\mathrm{CO}$ dihitung energi pembakaran untuk menghasilkan energi potensial yang dapat digunakan untuk menggerakkan piston.

\section{Perhitungan Energi Pembakaran}

Perhitungan nilai energi reaksi pembakaran diperoleh dengan mensinkronkan antara data uji emisi yang diperoleh secara eksperimen dan teori stokiometri serta themodinamika terkait dengan pembakaran. Prosedur penentuan nilai energi pembakaran adalah sebagai berikut:

1. Tentukan perbandingan emisi gas buang $\mathrm{CO}$ dan $\mathrm{CO}_{2}$ berdasarkan hasil uji emisi gas buang $\mathrm{CO}$ dan $\mathrm{CO}_{2}$ (Tabel 4).

2. Buat persamaan reaksi stokiometri pembakaran tak sempurna dan setarakan reaksi tersebut dengan bantuan data perbandingan $\mathrm{CO}$ dan $\mathrm{CO}_{2}$

3. Tentukan energi reaksi pembakaran dengan data nilai entalpi pembentukan standar molekul $\left(\Delta H^{\circ} f\right)$

Energi reaksi pembakaran dirumuskan dengan:

$\Delta \mathrm{H}^{\mathrm{o}}$ f reaksi pembakaran $=\sum \Delta \mathrm{H}^{\circ} \mathrm{f}$ produk -

$$
\sum \Delta \mathrm{H}^{\mathrm{o}} \mathrm{f} \text { reaktan }
$$

Data nilai entalpi pembentukan molekul pada Tabel 3 diperlukan untuk menghitung Energi pembakaran.

Tabel 3. Nilai entalpi pembentukan standar $\left(\Delta \boldsymbol{H}^{\circ} \boldsymbol{f}\right)$ (Tesfa, Belachew, Gu, Fengshou, Mishra, Rakesh and Ball, Andrew. 2013).

\begin{tabular}{lc}
\hline Molekul & $\begin{array}{c}\text { Entalpi Pembentukan Standar }\left(\Delta H^{\circ} f\right) \\
(\mathrm{kJ} / \mathrm{mol})\end{array}$ \\
\hline $\mathrm{C}_{8} \mathrm{H}_{18}$ & -249.73 \\
$\mathrm{C}_{2} \mathrm{H}_{6} \mathrm{O}$ & -277.7 \\
$\mathrm{O}_{2}$ & 0 \\
$\mathrm{~N}_{2}$ & 0 \\
$\mathrm{CO}_{2}$ & -393.52 \\
$\mathrm{CO}$ & -110.53 \\
$\mathrm{H}_{2} \mathrm{O}$ & -285.82 \\
\hline
\end{tabular}

Selanjutnya hasilnya dibandingkan antara energi pembakaran hasil perhitungan teori, pengukuran di laboratorium thermodinamika BPPT, dan energi untuk menghasilkan medan elektromagnet. Apakah penggunaan elektromagnet pada mesin bensin mengakibatkan energi yang dihasilkannya menjadi tekor?

\section{HASIL DAN PEMBAHASAN}

Bensin $\mathrm{C}_{8} \mathrm{H}_{18}$ mengandung unsur lain diantaranya abu, belerang, timbal. $u$ Unsur ini yang menyebabkan pembakaran tidak sempurna. Bioetanol $\mathrm{C}_{2} \mathrm{H}_{5} \mathrm{OH}$ merupakan bahan bakar dengan nilai oktan tinggi dan termasuk bahan bakar ramah lingkungan. Kedua bahan bakar ini digabungkan dengan komposisi (E0, E10, E20 dan E30). Untuk menentukan besarnya energi pembakaran dibutuhkan data pengujian emisi gas buang dan persamaan stokiometri reaksi pembakaran sempurna. Adapun hasil uji emisi gas buang terlihat pada Gambar 3. 

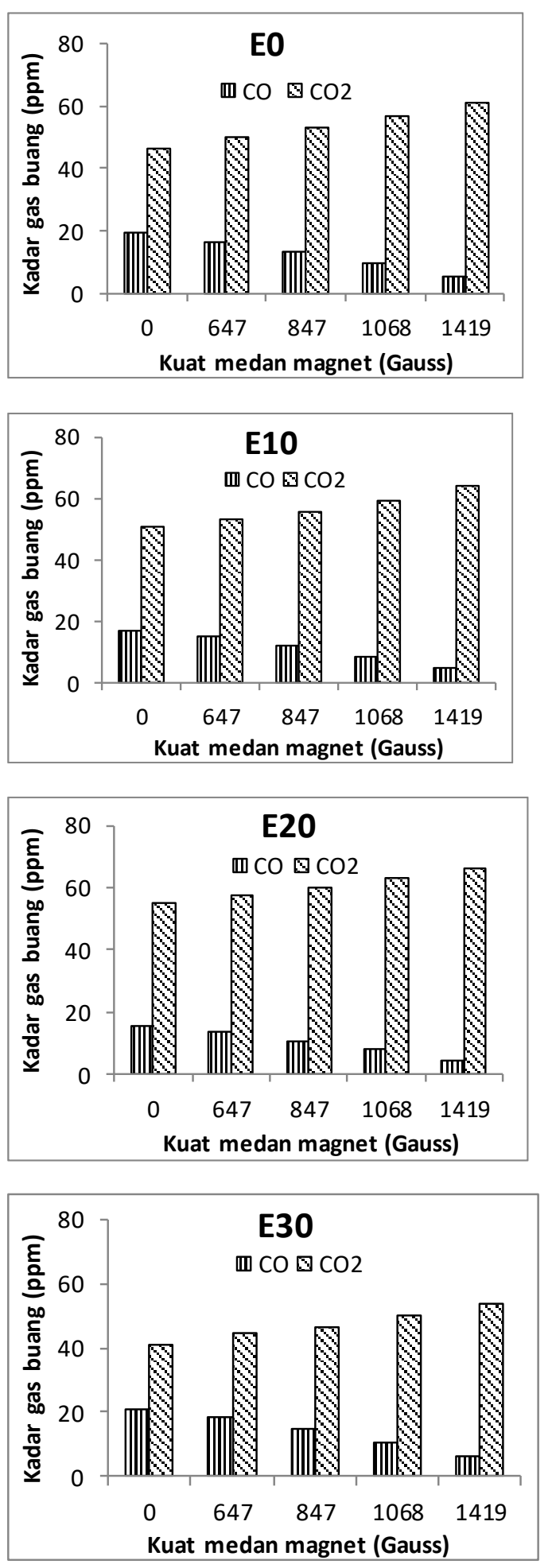

Gambar 3. Grafik hubungan antara karbon monoksida (CO) dan karbon dioksida $\left(\mathrm{CO}_{2}\right)$ dengan kuat medan magnet pada berbagai komposisi bahan bakar

Gambar 3 yaitu grafik hubungan antara kadar $\mathrm{CO}_{2}$ dan CO untuk semua komposisi bahan bakar baik yang dimagnetisasi maupun yang tidak. Tampak bahwa semua bahan bakar uji (E0, E10, E20 dan E30) yang dimagnetisasi kadar $\mathrm{CO}_{2}$ meningkat sedang $\mathrm{CO}$ menurun. Makin besar medan elektromagnet yang diberikan pada bahan bakar maka makin tinggi kenaikan kadar $\mathrm{CO}_{2}$ dan makin turun kadar $\mathrm{CO}$. Untuk bahan bakar E0, kadar $\mathrm{CO}_{2}$ meningkat hingga $32 \%$ sedang $\mathrm{CO}$ turun hingga $71 \%$. Untuk bahan bakar E10, kadar $\mathrm{CO}_{2}$ meningkat hingga $25 \%$ sedang $\mathrm{CO}$ turun hingga $71 \%$. Untuk bahan bakar E20, kadar $\mathrm{CO}_{2}$ meningkat hingga $20 \%$ sedang CO turun hingga $71 \%$. Untuk bahan bakar E30, kadar $\mathrm{CO}_{2}$ meningkat hingga $32 \%$ sedang $\mathrm{CO}$ turun hingga $71 \%$. Hal ini disebabkan medan elektromaget mampu menggetarkan (meresonansi) ion hidrokarbon dalam bahan bakar. Artinya medan magnet yang dibeikan pada bahan bakar menyebabkan resonansi atau vibrasi pada partikel bahan bakar. kondisi ini menyebabkan rantai hidrokarbon menjadi tidak stabil. $\mathrm{hH}$ Hal ini dapat memperlemah bahkan bila medan magnet cukup besar dapat memecah rantai hidrokarbon sehingga terjadi ionisasi pada hidrokarbon. Ionisasi diperlukan agar bahan bakar dapat dengan mudah mengikat oksigen selama proses pembakaran, sehingga campuran bahan bakar dan oksigen dapat terbakar mendekati sempurna.
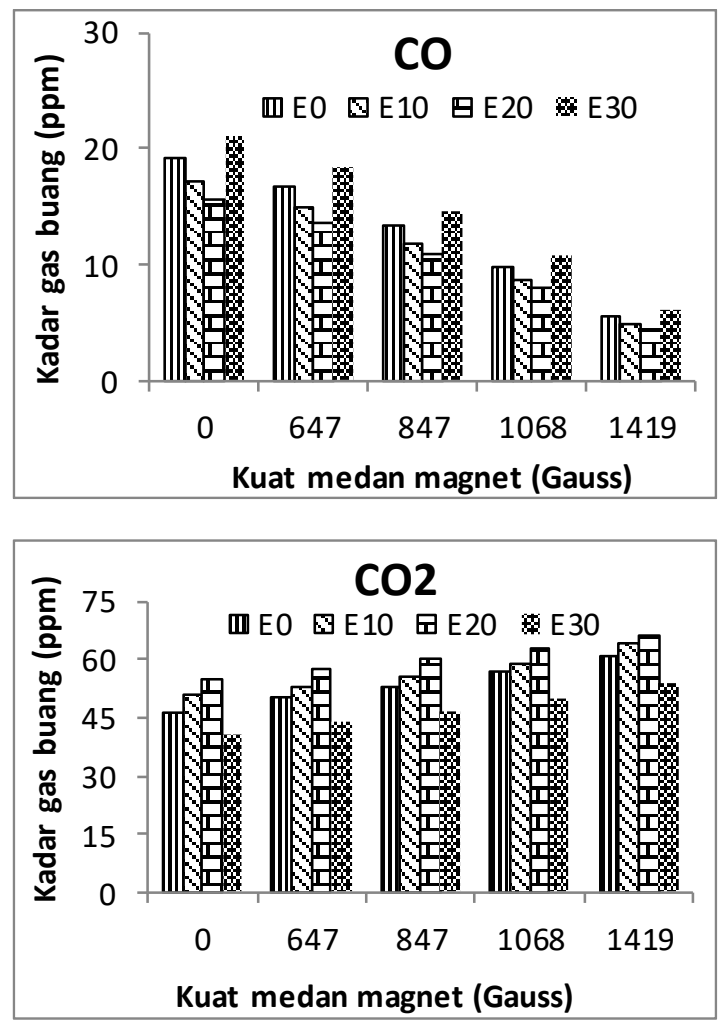

Gambar 4. Grafik hubungan antara karbon monoksida (CO) dan karbon dioksida $\left(\mathrm{CO}_{2}\right)$ pada kuat medan magnet pada berbagai komposisi bahan bakar

Tabel 4 di bawah menunjukkan batas maksimum uji emisi gas buang untuk berbagai sepeda motor berdasarkan peraturan no.6 tahun 2009 Kementrian Lingkungan Hidup, bila Tabel 4 ini dibandingkan dengan Gambar 4, maka hasil pengujan bahan bakar yang dimagnetisasi jauh dibawah batas maksimum.

Kadar bioetanol yang meningkat memberi kontribusi terhadap penurunan $\mathrm{CO}$ dan peningkatan $\mathrm{CO}_{2}$, hal ini disebabkan karena bioetanol mempunyai unsur 
oksigen sedangkan premium tidak sehingga kandungan bioetanol dapat membantu proses pembakaran menjadi lebih mendekati sempurna (B. Sugiarto, 2018). Hal ini terlihat pada Gambar 4. Berbeda untuk kadar bioetanol $30 \%$ nilai $\mathrm{CO}$ meningkat dan $\mathrm{CO}_{2}$ turun. Ini disebabkan penggunaan campuran bioetanol dalam bensin $>25 \%$ menimbulkan temperatur pembakaran sendiri/flash point tinggi sehingga pembakaran yang homogen akan sulit tercapai pada tekanan kompresi di ruang bakar, sehingga kinerja mesin turun. Untuk konsentrasi bioetanol yang lebih besar harus menggunakan mesin yang sudah dimodifikasi atau mesin yang khusus untuk pemakaian bioetanol.

Tabel 4. Batas maksimum emisi gas buang (Kementrian Lingkungan Hidup dan Kehutanan, 2017)

\begin{tabular}{|l|c|c|c|}
\hline Kategori & Tahun & \multicolumn{2}{|c|}{ Parameter } \\
\cline { 3 - 4 } & pembuatan & $\begin{array}{c}\mathrm{CO} \\
(\mathrm{ppm})\end{array}$ & $\begin{array}{c}\mathrm{HC} \\
(\mathrm{ppm})\end{array}$ \\
\hline $\begin{array}{c}\text { Sepeda motor } \\
\text { 2 langkah }\end{array}$ & $<2010$ & 25 & 12000 \\
\hline $\begin{array}{c}\text { Sepeda motor } \\
\text { 4 langkah }\end{array}$ & $<2010$ & 35 & 2400 \\
\hline $\begin{array}{c}\text { Sepeda motor } \\
\text { 2 langkah dan } \\
\text { 4 langkah }\end{array}$ & $>2010$ & 22 & 2000 \\
\hline
\end{tabular}

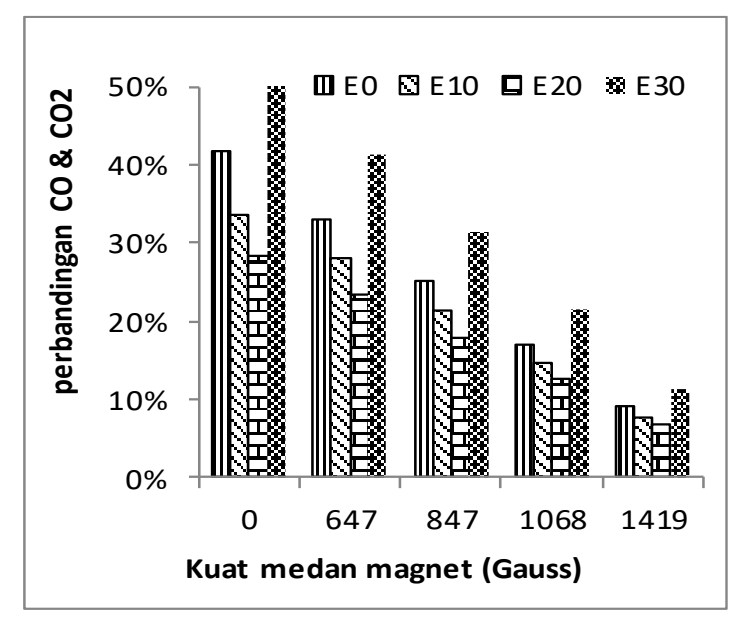

Gambar 5. Grafik hubungan antara perbandingan karbon monoksida $(\mathrm{CO})$ dan karbon dioksida $\left(\mathrm{CO}_{2}\right)$ terhadap kuat medan magnet pada berbagai komposisi bahan bakar

Gambar 5 memperlihatkan persentase $\mathrm{CO}$ dan $\mathrm{CO}_{2}$ tampak bahwa medan elektromagnet dapat memperkecil perbandingan tersebut atau dengan kata lain dapat meningkatkan kadar $\mathrm{CO}_{2}$ seperti dijelaskan sebelumnya bahwa magnet ini dapat membuat molekul bahan bakar terionisasi sehingga hal ini menyebabkan mudah terjadi pembakaran yang mendekati sempurna. Persamaan reaksi pembakaran sempurna:
$\mathrm{C}_{8} \mathrm{H}_{18}+12,5\left(\mathrm{O} 2+3,71 \mathrm{~N}_{2}\right)$ $46,37 \mathrm{~N}_{2}+$ Energi.

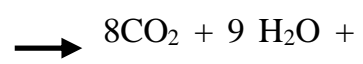

$$
\mathrm{C}_{2} \mathrm{H}_{5} \mathrm{OH}+3\left(\mathrm{O}_{2}+3,71 \mathrm{~N} 2\right) \longrightarrow 2 \mathrm{CO}_{2}+3 \mathrm{H}_{2} \mathrm{O}+11,13
$$$$
\mathrm{N}_{2}+\text { Energi. }
$$

Dari Gambar 5 dan persamaan stokiometri untuk pembakaran sempurna persamaan (1) dan (2) dapat ditentukan persamaan stokiometri untuk pembakaran tak sempurna. Penyetaraan reaksi pembakaran tak sempurna menggunakan bantuan data perbandingan gas buang $\mathrm{CO}$ dan $\mathrm{CO}_{2}$. Data perbandingan gas $\mathrm{CO}$ dan $\mathrm{CO}_{2}$ yang terdapat pada Gambar 5 diperoleh dari data hasil uji emisi yang terlihat dalam Tabel 5.

Misalnya untuk bahan bakar E0 (100\% bensin) tanpa magnetisasi diperoleh perbandingan kadar $\mathrm{CO}$ dan $\mathrm{CO}_{2}=41.6 \%$, data tersebut menjadi dasar untuk penyetaraan reaksi stokiometri pembakaran tak sempurna. Koefisien $\mathrm{CO}_{2}$ yang pada pembakaran sempurna persamaan (1) adalah 8, berubah menjadi 4.67 karena pada pembakaran tak sempurna menghasilkan $41.6 \%$ CO, maka persamaan reaksi pembakaran tak sempurna E0 tanpa magnetisasi adalah sebagai berikut :

$\mathrm{C}_{8} \mathrm{H}_{18}+10.84\left(\mathrm{O}_{2}+3.71 \mathrm{~N}_{2}\right) \longrightarrow 4.67 \mathrm{CO}_{2}+3.33$
$\mathrm{CO}+9 \mathrm{H}_{2} \mathrm{O}+40.2 \mathrm{~N}_{2}+$ Energi

Untuk menyetarakan reaksi pembakaran tak sempurna bahan bakar E0, E10, E20 dan E30, langkah pertama adalah membuat persamaan reaksi pembakaran sempurnanya terlebih dahulu. Kemudian, berdasarkan data perbandingan gas $\mathrm{CO} / \mathrm{CO}_{2}$ dapat disetarakan reaksi pembakaran tak sempurna dari masing-masing jenis bahan bakar tanpa maupun dengan magnetisasi.

Untuk bahan bakar campuran $90 \%$ vol bensin dan $10 \%$ vol bioetanol (E10), reaksi pembakaran sempurnanya adalah sebagai berikut :

$$
\left.\begin{array}{rl}
0.9 \mathrm{C}_{8} \mathrm{H}_{18} \\
0.1 \mathrm{C}_{2} \mathrm{H}_{6} \mathrm{O}
\end{array}\right\} \begin{aligned}
& +11.55\left(\mathrm{O}_{2}+3.71 \mathrm{~N}_{2}\right) \rightarrow \\
& 7.4 \mathrm{CO}_{2}+8.4 \mathrm{H}_{2} \mathrm{O}+42.85 \mathrm{~N}_{2}+\text { Energi }
\end{aligned}
$$

Data perbandingan $\mathrm{CO} / \mathrm{CO}_{2}=33.7 \%$ untuk bahan bakar E10 tanpa magnetisasi, sehingga koefisien $\mathrm{CO}_{2}$ yang pada pembakaran sempurna E10 adalah 7.4, berubah menjadi 4.91 karena pada pembakaran tak sempurna menghasilkan $33.7 \% \mathrm{CO}$, maka persamaan reaksi pembakaran tak sempurna E10 tanpa magnetisasi adalah sebagai berikut :

$$
\left.\begin{array}{rl}
0.9 \mathrm{C}_{8} \mathrm{H}_{18} \\
\mathrm{C}_{2} \mathrm{H}_{6} \mathrm{O}
\end{array}\right\} \begin{aligned}
& +10.25\left(\mathrm{O}_{2}+3.71 \mathrm{~N}_{2}\right) \rightarrow \\
& 4.91 \mathrm{CO}_{2}+2.49 \mathrm{CO}+8.4 \mathrm{H}_{2} \mathrm{O}+0.1 \\
& 38.04 \mathrm{~N}_{2}+\text { Energi }
\end{aligned}
$$

Untuk bahan bakar campuran $80 \%$ vol bensin dan $20 \%$ vol bioetanol (E20), reaksi pembakaran sempurnanya adalah sebagai berikut :

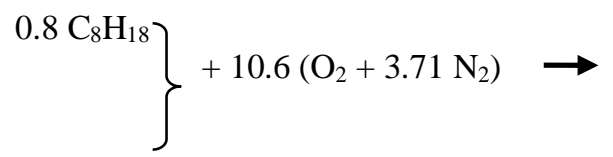




$$
6.8 \mathrm{CO}_{2}+7.8 \mathrm{H}_{2} \mathrm{O}+39.32 \mathrm{~N}_{2}+\text { Energi }
$$

\section{$0.2 \mathrm{C}_{2} \mathrm{H}_{6} \mathrm{O}$}

Data perbandingan $\mathrm{CO} / \mathrm{CO}_{2}=28.3 \%$ untuk bahan bakar E10 tanpa magnetisasi.

E20 adalah 6.8, berubah menjadi 4.87 karena pada pembakaran tak sempurna menghasilkan $28.3 \% \mathrm{CO}$, maka persamaan reaksi pembakaran tak sempurna E20 tanpa magnetisasi adalah sebagai berikut :

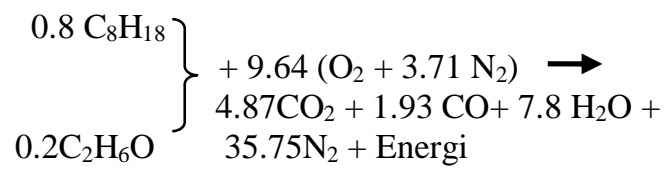

Untuk bahan bakar campuran $70 \%$ vol bensin dan 30\% vol bioetanol (E30), reaksi pembakaran sempurnanya adalah sebagai berikut :

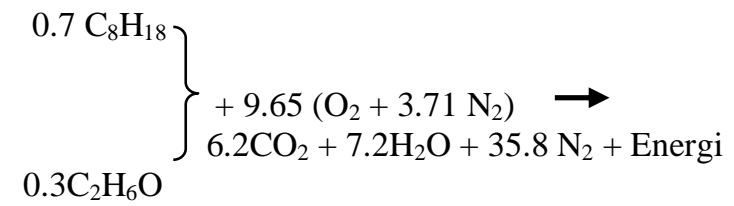

Data perbandingan $\mathrm{CO} / \mathrm{CO}_{2}=52 \%$ untuk bahan bakar E30 tanpa magnetisasi, sehingga koefisien $\mathrm{CO}_{2}$ yang pada pembakaran sempurna E30 adalah 6.2, berubah menjadi 2.98 karena pada pembakaran tak sempurna menghasilkan $52 \% \mathrm{CO}$, maka persamaan reaksi pembakaran tak sempurna E30 tanpa magnetisasi adalah sebagai berikut :

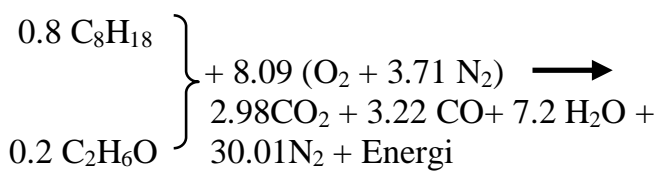

Selanjutnya dihitung energinya seperti pada Tabel 6 menggunakan persamaan Thermodinamika

$$
\Delta \mathrm{H}^{\mathrm{o}} \text { reaksi pembakaran }=\sum_{\Sigma \Delta \mathrm{H}^{\circ} \text { f reaktan }} \Delta \mathrm{H}^{\circ} \text { f produk }-
$$

Tabel 6 Perhitungan energi pembakaran E0 tanpa magnetisasi

\begin{tabular}{lccc}
\hline Molekul & $\begin{array}{c}\text { Entalpi } \\
\text { dasar } \\
(\mathrm{kJ} / \mathrm{mol})\end{array}$ & $\begin{array}{c}\text { Entalpi } \\
\text { reaktan } \\
(\mathrm{kJ} / \mathrm{mol})\end{array}$ & $\begin{array}{c}\text { Enltalpi } \\
\text { produk } \\
(\mathrm{kJ} / \mathrm{mol})\end{array}$ \\
\hline $\mathrm{C} 8 \mathrm{H} 18$ & -249.73 & -249.73 & \\
$\mathrm{C} 2 \mathrm{H} 6 \mathrm{O}$ & -277.70 & & \\
$\mathrm{O} 2$ & 0 & 0 & \\
$\mathrm{~N} 2$ & 0 & 0 & \\
$\mathrm{CO} 2$ & -393.52 & & -1838.48 \\
$\mathrm{CO}$ & -110.53 & & -3.67 .86 \\
$\mathrm{H} 2 \mathrm{O}$ & -285.82 & & -2572.38 \\
$\mathrm{~N} 2$ & 0 & & 0 \\
\hline \multicolumn{7}{c}{ Total } & -249.73 & -4778.72 \\
\hline
\end{tabular}

$\Delta \mathrm{H}^{\circ}$ reaksi pembakaran $=\sum \Delta \mathrm{H}^{\circ}$ f produk $\sum \Delta \mathrm{H}^{\circ}$ f reaktan $=-4778.72+249.7$

$$
=-4528.99 \mathrm{~kJ} / \mathrm{mol}
$$

Prosedur di atas diulang untuk mendapatkan nilai energi pembakaran bahan bakar lain untuk yang

\begin{tabular}{|c|c|c|c|c|}
\hline $\begin{array}{l}\text { Bahan } \\
\text { Bakar }\end{array}$ & $\begin{array}{l}\text { Medan } \\
\text { EM } \\
\text { (Gauss) }\end{array}$ & $\begin{array}{c}\text { Energi } \\
\text { pembakaran } \\
\text { Teori }(\mathrm{kJ})\end{array}$ & $\begin{array}{c}\text { Energi } \\
\text { Pembakaran } \\
\text { Lab BPPT } \\
(\mathrm{kJ})\end{array}$ & $\begin{array}{l}\text { Kelebihan } \\
\text { energi }(\mathrm{kJ})\end{array}$ \\
\hline \multirow{5}{*}{ E0 } & 0 & -4528.99 & -5639.98 & 0 \\
\hline & 647 & -4722.03 & -5646.19 & -193.04 \\
\hline & 847 & -4901.42 & -5650.97 & -372.43 \\
\hline & 1068 & -5083.18 & -5657.65 & -554.19 \\
\hline & 1419 & -5264.47 & -5656.22 & -735.48 \\
\hline \multirow{5}{*}{ E10 } & 0 & -4355.54 & -5124.48 & 0 \\
\hline & 647 & -4474.91 & -5148.17 & -119.37 \\
\hline & 847 & -4611.49 & 5152.76 & -255.95 \\
\hline & 1068 & -4752.74 & -5158.14 & -397.20 \\
\hline & 1419 & -4898.23 & -5166.67 & -542.69 \\
\hline \multirow{5}{*}{ E20 } & 0 & -4105.10 & -4591.33 & 0 \\
\hline & 647 & -4197.41 & -4608.57 & -92.31 \\
\hline & 847 & -4304.42 & $-4612 . .35$ & -199.32 \\
\hline & 1068 & -4408.12 & -4618.66 & -303.02 \\
\hline & 1419 & -4518.95 & -4621.60 & -413.85 \\
\hline \multirow{5}{*}{ E30 } & 0 & -3327.22 & -3875.14 & 0 \\
\hline & 647 & -3514.22 & -3878.27 & -187.00 \\
\hline & 847 & -3688.01 & -3880.63 & -360.79 \\
\hline & 1068 & -3864.08 & -3887.29 & -536.86 \\
\hline & 1419 & -4039.72 & -3893.95 & -712.50 \\
\hline
\end{tabular}
dimagnetisasi maupun tidak, hasil perhitungan terlihat pada Tabel 7.

Tabel 7. Energi pembakaran

Tabel 7 menyajikan energi pembakaran. Kolom satu menginformasikan jenis bahan bakar yang digunakan pada penelitian. Kolom kedua menunjukkan besarnya medan elektromagnet yang digunakan, kolom ketiga energi pembakaran yang dihitung secara teori dibantu dengan hasil pengujian uji emisi $\mathrm{CO}_{2}$ dan $\mathrm{CO}$, kolom keempat energi pembakaran yang diperoleh dari hasil uji di laboratorium Thermodinamika BPPT. Kolom kelima menunjukkan perbedaan energi antara bahan bakar yang diberi medan magnet dan tidak diberi medan magnet berdasarkan teori (dasar perhitungan menggunakan kolom ketiga). Perbedaan Energi yang diperoleh dari teori dan hasil uji lab disebabkan dalam perhitungan teori menganggap bahwa bahan bakar tersebut murni terdiri dari hidrokarbon saja. Sementara pada kenyataan bahan bakar yang ada di pasaran itu banyak unsur campuran inilah yang menyebabkan nilai uji lab lebih besar dari perhitungan teori.

Berdasarkan data Tabel 7 untuk seluruh bahan bakar bila dilalui medan elektromagnet menyebabkan energi pembakaranya meningkat. Makin besar medan elektromagnet yang diberikan pada bahan bakar, maka makin besar pula energi pembakarannya atau kualitas pembakaran makin baik. hal ini disebabkan medan elektromaget mampu menggetarkan (meresonansi) ion 
hidrokarbon dalam bahan bakar. Makin besar medan elektromagnet makin besar pula ionisasi hidrokarbon yang terjadi, sehingga makin mudah bahan bakar untuk mengikat oksigen selama proses pembakaran yang pada akhirnya akan terbentuk pembakaran yang mendekati sempurna.

\section{KESIMPULAN}

Penggunaan medan elektromagnet pada bahan bakar dapat meningkatkan kualitas pembakaran, hal ini terbukti dengan meningkatnya kadar $\mathrm{CO}_{2}$ hingga $35 \%$ dan menurunkan kadar CO hingga $71 \%$. Selain itu penggunaan medan elektromagnet dapat meningkatkan energi pembakaran berkisar 13-21\%. Makin besar medan elektromagnet yang diberikan, maka energi pembakaran makin besar. Energi untuk menghasilkan medan elektromagnet jauh lebih kecil dibandingkan dengan energi hasil pembakaran.

\section{DAFTAR PUSTAKA}

Agathou, M. S., \& Kyritsis, D. C. (2012). Electrostatic atomization of hydrocarbon fuels and bio-alcohols for engine applications. Energy Conversion and Management, $60, \quad 10-17$. http://doi.org/10.1016/j.enconman.2012.01.019

Chaware, K. (2015). Review on Effect of Fuel Magnetism by Varying Intensity on Performance and Emission of Single Cylinder Four Stroke Diesel Engine. International Journal of Engineering and General Science, 3(1), 11741178.

Kementrian Lingkungan Hidup dan Kehutanan. Peraturan Menteri Lingkungan Hidup Dan Kehutanan Republik Indonesia. Nomor P.20/MENLHK/Setjen/Kum.1/3/2017 Tentang Baku Mutu Emisi Gas Buang Kendaraan Bermotor (2017).

Kolhe, A. V, Shelke, R. E., \& Khandare, S. S. (2014). Performance, Emission and Combustion Characteristics of a Variable Compression Ratio Diesel Engine Fueled with Karanj Biodiesel and Its Blends. Jordan Journal of Mehanical and INdutrial Engineering, 8(4), 806-813.

Nufus, T. H., Praeko, R., Setiawan, A., \& Hermawan, W. (2017). Characterization of biodiesel fuel and its blend after electromagnetic exposure. Cogent Engineering, 75, 1-12. http://doi.org/10.1080/23311916.2017.1362839

Syarifuddin, A., Tony, M. S. K., \& Utomo, S. (2016). Performa Dan Emisi Gas Buang Mesin Bensin Dengan Sistem Egr Panas Pada Campuran Bahan Bakar Premium Dan High Purity Methanol. Jurnal Mekanikal, 7(1), 652-661.

Yamaha, 2020. Spesifikasi sepeda motor 4 langkah. Retrieved from https://www.yamahamotor.co.id/product/mio-m3-125/

Singh AK, Solank RM. 2013, Investigation of fuel saving in annealing lehr through magnetic material fuel sarver, International Journal of Science and Research.6(14): 178-180.

Siregar H, Nainggolan R. 2012. Electromagnetic Fuel Saver for Enhanching The Performance of The Diesel Engine. Global Journal of Research in Engineering Mechanical and Mechanics Engineering. Global Journal Inc (USA). 12(6):14.

Subbarayan MR, Kumaar JSS, Padmanaban MRA. 2016. Experimental investigation of evaporation rate and exhaust emissions of diesel engine fuelled with cotton seed methyl ester and its blend with petro-diesel. 48:369-377. doi:10.1016/j.trd.2016.08.024.

Tesfa, Belachew, Gu, Fengshou, Mishra, Rakesh and Ball, Andrew. 2013. LHV Predication Models and LHV Effect on the Performance of CI Engine Running with Biodiesel Blends. Energy Conversion and Management, 71. pp. 217-226. ISSN 0196-8904

Mariaca, A. G. and Castaño, R. M. Anhydrous 2018. Bioethanol gasoline blends at high altitude above sea level in a SI engine. Biofuels. Taylor \& Francis. 2018. pp.1759-7269. doi: 10.1080/17597269.2018.1479134.

B. Sugiarto, C. S. Wibowo, A. Zikra, A. Budi, and T. Mulya, "Characteristic of Gasoline Fuels in Indonesia Blend with Varying Percentages of Bioethanol," in E3S Web of Conferences, 2018, vol. 2031, pp. 1-4.

L. S. Khuong, H. H. Masjuki, N. W. M. Zulki, E. N. Mohamad, and M. A. Kalam. 2017. "properties and lubrication characteristics of," R. Soc. Chem., vol. 7, pp. 15005-15019..

R. A. S. N and B. Sudarmanta, (2018). "Experimental Study on the Effect of Heating Temperature on Bioethanol Injector to Spray Characteristics for Application on Sinjai-150 Engine," in AIO Conference Proceedings, vol. 20029. 